\title{
Efficiency of four types of beetles traps in rubber plantation in the Southern of Côte d'Ivoire
}

\author{
Bleu Gondo DOUAN ${ }^{1 *}$, Franceline $\mathrm{DOH}^{1}$, Aubin Silvère Djiwha DANON ${ }^{2}$, \\ N'djiha Isabelle BEUGRE ${ }^{3}$, Donatié Serge TOURÉ ${ }^{1}, N^{\prime}$ doua Bertrand GUINAGUI ${ }^{4}$ and \\ Mamadou DOUMBIA ${ }^{2}$ \\ ${ }^{1}$ University Peleforo Gon Coulibaly, Department of Animal Biology, BP 1328 Korogho, Côte d'Ivoire. \\ ${ }^{2}$ University Nangui Abrogoua, UFR-SN Department of Natural Sciences, 02 BP 801 Abidjan 02 Côte d'Ivoire. \\ ${ }^{3}$ National Agronomic Research Center, Rice program, Man station, BP 440 Man, Côte d'Ivoire. \\ ${ }^{4}$ University Félix Houphouët-Boigny, Pedagogical and Research Unit: Plant Physiology and Pathology, \\ Côte d'Ivoire. \\ *Corresponding author; E-mail: bleudouan80@gmail.com, Tél: +2250708323696
}

\author{
Received: 28-05-2021 $\quad$ Accepted: 27-10-2021 $\quad$ Published: 31-12-2021
}

\begin{abstract}
The current study focuses on different types of beetle's traps in rubber plantations in the localities of Bongo and Toupah, in the south of Côte d'Ivoire. The objective of this work is to determine the most efficient trap for capturing beetles in these agrosystems. Four trapping methods, namely yellow trap on the ground, yellow trap at height, screen trap and pitfall trap were used in plantations of different ages. The investigation resulted in more captures of beetles from the screen traps with means of 236.5 and 365.5 beetles in Toupah and Bongo, respectively. Pitfall traps captured fewer individuals (22.58 and 39.83 individuals from Toupah and Bongo, respectively). Yellow traps on the ground and height captured more individuals in 1 to 5 years aged plantations. Pitfall traps captured more individuals in 6 to 10 year aged plantations and screen traps captured more beetles in the forests. Beetle's family richness is higher in screen traps with means of 23.83 and 19 families, whereas the pitfall trap captured the fewest beetles' families with means of 8.58 and 6.58 families captured from Bongo and Toupah, respectively. Yellow ground traps, yellow height traps and screen traps captured more phytophagous beetles. However, pitfall traps captured more predators and fewer phytophagous. The screen trap appeared as the most effective and most suitable trap against beetles in rubber plantations.
\end{abstract}

(C) 2021 International Formulae Group. All rights reserved.

Keywords: Traps efficiency, beetle, abundance, rubber plantation, Côte d'Ivoire.

\section{INTRODUCTION}

Fauna study and especially that of insects in agrosystems requires the use of a certain type of trapping that depends on the expected results. Several traps have proven their effectiveness in different habitats. For example, pitfall traps are effective for the capture of Carabidae (Skvaria et al., 2017) and soil insects (Lang et al., 2011). Yellow traps capture more floricultural insects (Yattara et al., 2013) and screen and malaise traps are effective in intercepting flying insects (Kra, 2010; Lamarre et al., 2012; Chapelin, 2013). 
Rubber cultivation in Côte d'Ivoire started in 1955 (Keli et al., 2005) and has spread from primary growing areas to some socalled marginal areas (Ruf, 2008a and 2008b). However, there are scanty studies regarding insects in rubber agrosystems in Côte d'Ivoire (Tahiri and Mangué, 2007; Tahiri, 2010) and especially on beetles (Danon et al., 2017).

However, beetles are a very important group in understanding and interpreting an ecosystem. Indeed, beetles represent one third of the animal kingdom and are present in all ecosystems (Leraut, 2003). They are very diverse and represent both the largest and the smallest specimens of insects. Somme such as dung beetles participate in soil fertilization (Carpenato et al., 2005). Others such as ground beetles and ladybirds are predators and help reduce or control crop pests. Finally, different families of beetles are ecological indicators (Horgan, 2005; Moraes et al., 2013).

For better knowledge about beetles in rubber culture, the use and/or association of several traps could be affordable to reveal the diversity and the abundance of the insects of this environment. In this study, four trapping techniques (yellow trap on the ground, yellow trap in height, screen trap and pitfall trap) are used for beetle capture in rubber plantations aged from 1 to over 15 years and a full forest area. The work targets the effectiveness of these trapping systems for revealing the suitable trap in beetle capture in rubber agrosystems.

\section{MATERIALS AND METHODS Study site}

The study was achieved in two Integrated Agricultural Units of the African Society of Rubber Plantations in the localities of Toupah $\left(5^{\circ} 19^{\prime}\right.$ North latitude, $4^{\circ} 34^{\prime}$ West longitude) and Bongo (5 $29^{\prime}$ North latitude, $3^{\circ} 35^{\prime}$ West longitude). These sites are respectively located in Southern and SouthEastern Côte d'Ivoire (Figure 1). Toupah has a four equatorial season transition climate, two dry and two rainy seasons (Kangha et al., 2016). About the locality of Bongo, it has an equatorial climate, with two rainy and two dry seasons. The biggest rainy season starts from
mid-May to the end of June and the smallest from early October to mid-December (Abé, 2005).

\section{Description of traps}

Four types of traps, namely the yellow ground trap (Ty), the yellow height trap (Th), the screen trap (Ts) and the pitfall trap (Tf) were used to capture beetles

\section{Yellow traps}

They are traps built from yellow plastic bins of $15 \mathrm{~cm}$ in diameter and $10 \mathrm{~cm}$ deep. The bins placed on the ground are called yellow traps on the ground (Figure 2), while those placed on iron bars at different heights above the ground $(0.5 \mathrm{~m}, 1 \mathrm{~m}$ and $2 \mathrm{~m})$, are yellow traps on the height (Figure 3).

\section{Pitfall traps}

They were designed using the basal part of plastic pots, $10 \mathrm{~cm}$ in diameter and $10 \mathrm{~cm}$ deep. The container was placed in the soil so that its rim coincided with the ground level (Figure 4).

\section{Screen traps}

These are interception traps, designed to catch insects on the fly. The screen traps used and modified are those of Barbalat (1995). The traps consist of a rectangular frame $(1 \mathrm{~m} \times 0.8$ $\mathrm{m})$ of transparent plastic, supported by two pillars and placed $1.5 \mathrm{~m}$ above the ground.

The insect during flight strikes the frame and falls into a receptacle containing a mixture of soapy and salty water placed under the frame (Figure 5).

\section{Capture of Beetles}

The catch was carried out in rubber plantations of different ages. The choice of plantations was made according to the phenological stage of the plants. In each study area, plantations of 1 to 5 years, 6 to 10 years and over 15 years were selected, and the full rainy forest was taken as control. Beetles were collected monthly from November 2015 to October 2016 from a 1.5 ha sampling unit in both locations. Four transects of $200 \mathrm{~m}$ spaced $25 \mathrm{~m}$ were laid out. On each transect, 5 yellow ground traps, 5 pitfall traps spaced of $50 \mathrm{~m}, 1$ trap height and 1 screen trap were placed. The traps containing the mixture of soapy and salty 
water were placed on the sampler units the same day and the insects were collected 48 hours after the trapping.

\section{Conservation and identification of beetles}

The contents of the traps were sieved and the beetles collected were stored with $70 \%$ alcohol in pillboxes labelled according to the type of trap, the type of plantation, the date of collection and sampling area. Thus, insects were conveyed to the laboratory for the counting and the identification of the beetle's family. Identification keys for the recognition of families drawn from works by various authors including Delvare and Aberlenc
(1989), Hangay and Zborowski (2010) were used for the identification of insects.

\section{Data analysis}

The SATISTICA 7.1 software analyzed the data from identifications. One-way analysis of variance (ANOVA 1) was used to analyze the data regarding the beetles' abundance in different traps for each habitat, family richness, and the abundance of trophic groups in each trap. Before this, a logarithmic transformation was done to normalize the data and stabilize the variables that were not. Fisher's LSD test at 5\% significance allowed the averages classification into homogeneous groups.

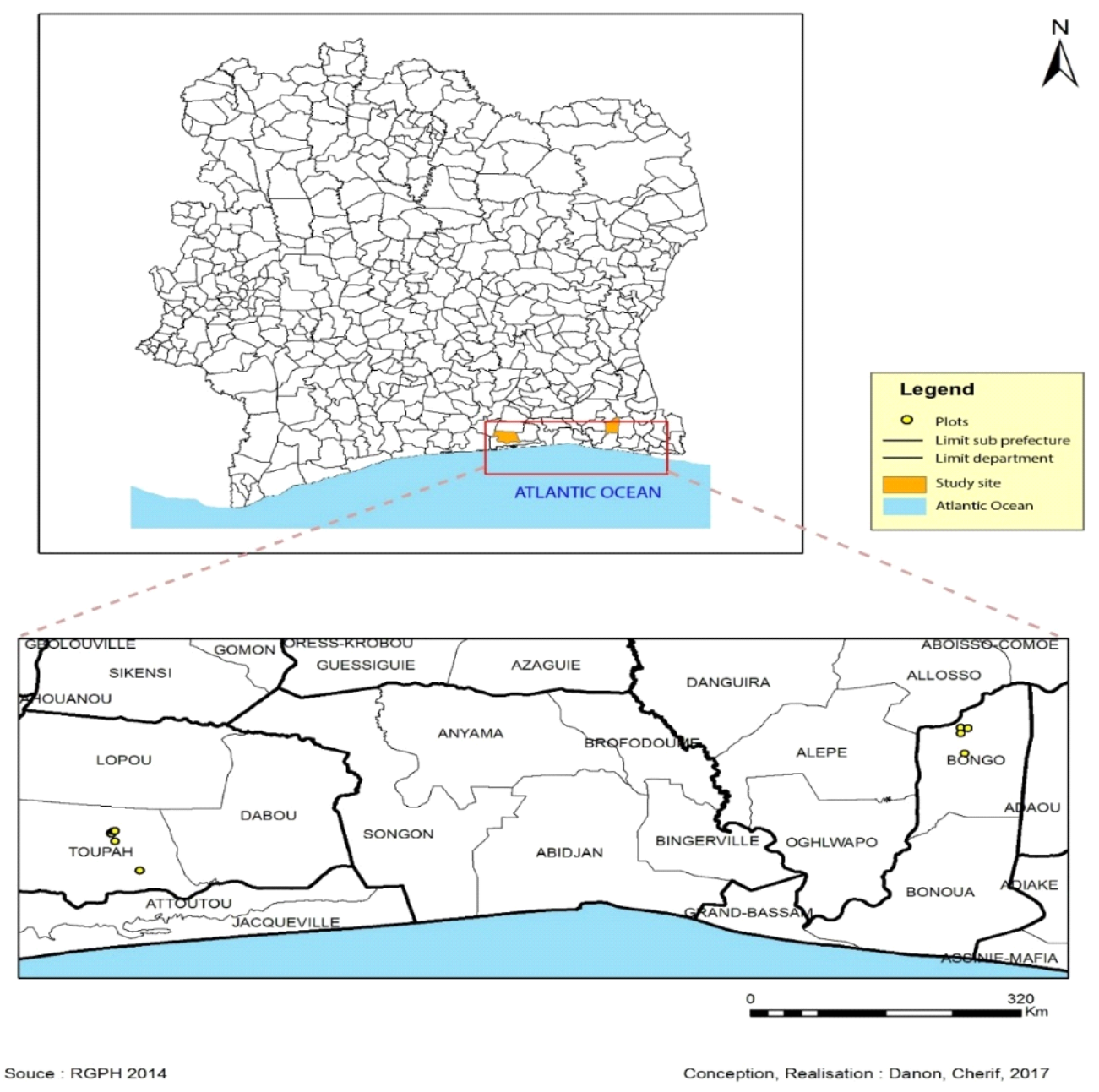

Figure 1: Study area. 


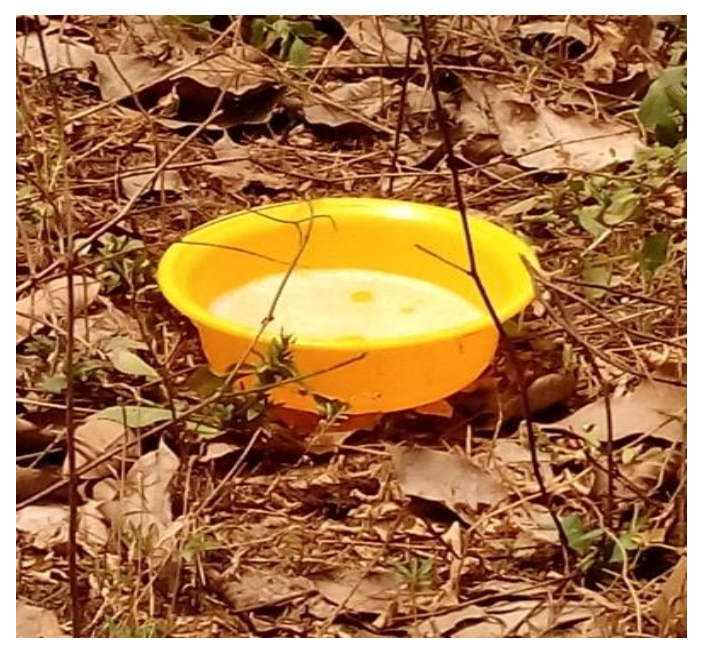

Figure 2: Yellow ground trap (Ty).

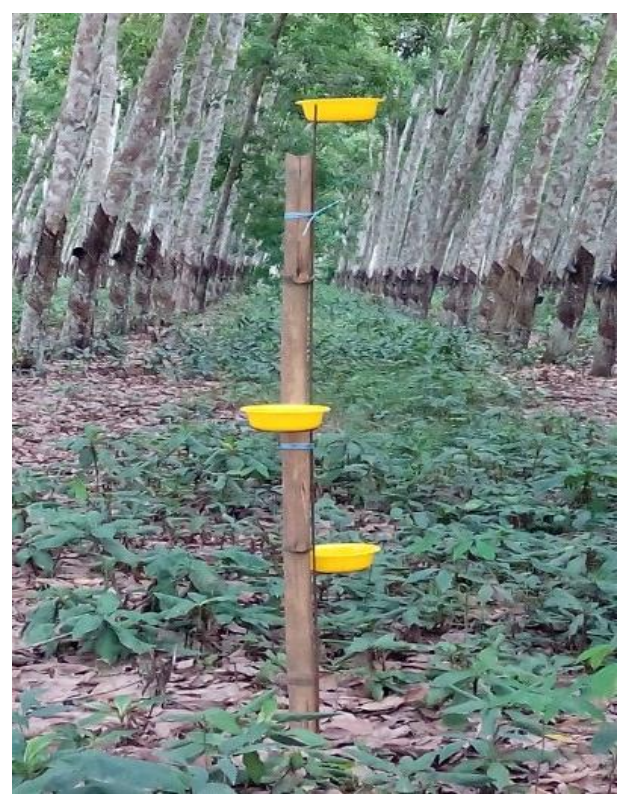

Figure 3: Yellow height trap (Th).

\section{RESULTS}

\section{Effectiveness of the trapping techniques}

The overall traps investigated allowed the capture of 10,874 beetles. The areas of Toupah and Bongo respectively recorded 4,144 and 6,730 ants' specimens. The sizes of ants capture per trap showed the highest proportion of captures from the screen traps in both

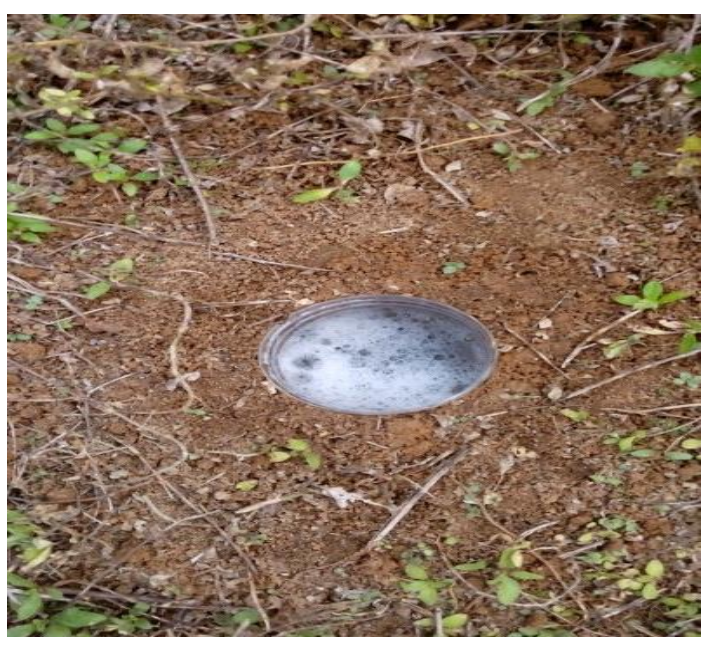

Figure 4: Pitfall trap (Tf).

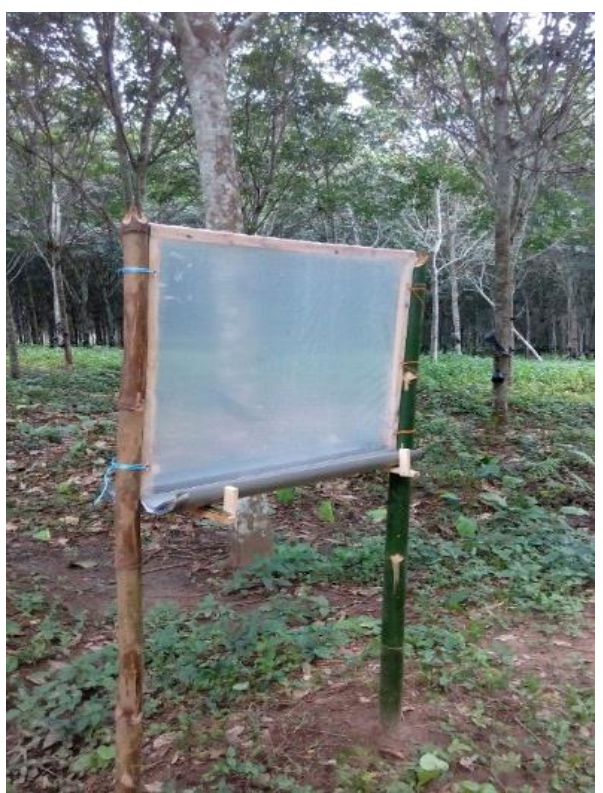

Figure 5: Screen trap (Ts).

Toupah and Bongo localities, with respective rates of $68.43 \%$ and $65.13 \%$. The pitfall traps provided the lowest proportions, with $6.84 \%$ captures in Toupah and $7.80 \%$ captures in Bongo (Figures 6 and 7).

Regarding the efficiency of the trapping techniques, the statistical analyzes showed significant differences $(\mathrm{p}<0.001)$ between the mean beetles numbers collected from various 
trapping system achieved in Toupah as well as in Bongo.

Thus, in both areas, screen traps were the most effective with respective averages of $236.5 \pm 38.9$ and $365.5 \pm 26.12$ beetles collected in Toupah and Bongo. Pitfall traps were the least effective with averages of $22.58 \pm 2.49$ beetles collected at Toupah and $39.83 \pm 5.26$ beetles at Bongo (Figures 8 and 9).

\section{Beetles abundance in traps within plantations}

In general, the results show us that the screen trap in comparison with the other types of traps, proved to be most effective in each habitat and un the two study areas with a highly significantly difference $(\mathrm{p}<0.001)$ (Tables 1 and 2).

\section{Captures from the yellow ground trap}

Ground yellow traps captured 1,042 beetle's individuals within plantations in Bongo and 583 individuals in Toupah. However, in both sites studied, the insects' individuals captured using such traps significantly differed $(\mathrm{p}<0.001)$ according to the type of plantation.

Plantations of 1 to 5 years of age were the habitats in which this trapping technique has captured the most individuals, with averages of $42.08 \pm 5.22$ (Bongo) and $19.33 \pm 1.62$ (Toupah). The lowest captures size from Bongo site derived from the control forest area (12 \pm 2.64 individuals), whereas that observation resulted in the plantation over 15 years of age from Toupah ( $8 \pm 2.24$ individuals), as shown in Tables 1 and 2.

\section{Capture from the pitfall trap}

The Pitfall trap captured 796 beetles in both areas with 271 individuals in Toupah and 525 in Bongo. The 6 to 10 years old plantations were the habitats in which this trap captured the most individuals with an average of $16.91 \pm$ 2.68 and $9.08 \pm 1.78$ beetles respectively in Bongo and Toupah. The smallest catches were made in Bongo in the plantation aged over 15 years with $4.91 \pm 1.2$ individuals on average. Regarding the locality of Toupah, the lowest catches were made in the forest $(2.41 \pm 0.7$ individuals on average) (Tables 1 and 2). The comparison of the catches made between the plantations by one-way analysis of variance gave a highly significant difference $(\mathrm{p}<0.001)$ in Bongo and a significant difference in Toupah $(\mathrm{p}=0.004)$.

\section{Capture made by the yellow height trap}

The yellow trap in height has collected 1234 beetles, with 454 individuals in Toupah and 780 in Bongo. The highest catches were made in plantations 1 to 5 years old, with an average of $28.55 \pm 7.87$ in Bongo and $13.5 \pm$ 1.85 in Toupah. The lowest catches were made in the bongo forest $(8.5 \pm 1.04)$ and Toupah $(2.58 \pm 0.77)$. The comparison of catches made between plantations by one-way analysis of variance gave a highly significant $(\mathrm{p}<0.001)$ difference to Toupah and a significant difference $(\mathrm{p}=0.022)$ to Bongo (Tables 1 and 2).

\section{Capture made by the screen trap}

Screen traps captured 4383 individuals in all bongo plantations and 2836 individuals in Toupah. Forests were the habitats in which this trap captured the most individuals with an average of $161.66 \pm 23.4$ and $102.91 \pm 23.39$ respectively in Bongo and Toupah. The lowest catches were obtained in the 6- to 10-year-old plantation with $54 \pm 7.5$ individuals and the 15 year-old plantation with $45.16 \pm 10.54$ individuals on average in Bongo and Toupah, respectively. The comparison of catches made between plantations by one-way analysis of variance yielded a highly significant difference with $\mathrm{p}<0.001$ at bongo and $\mathrm{p}=0.041$ at Toupah (Tables 1 and 2).

\section{Family wealth of beetles in traps}

The results concerning the family wealth of beetles in traps, show that the average family size is largely high within the screen traps in both areas, with $19 \pm 0.76$ and $23.83 \pm$ 1.39 families on average respectively in Toupah and Bongo. Pit traps were the traps in which the family wealth is the lowest with 6.58 \pm 0.04 average workforce in Toupah and 8.58 \pm 0.35 in Bongo. The comparison of family richness in traps by one-way analysis of variance yielded a highly significant difference in both areas ( $p<0.001)$ (Figures 10 and 11). 


\section{Abundance of beetles' trophic groups from the trapping techniques}

The different families of beetles captured were classified on the basis of their trophic function in their habitat. Three trophic groups were thus recorded, namely the detritiphagous (dominated by Scydmaenidae, Scarabaeidae, and Tenebrionidae families), the predators (Coccinellidae, Carabidae, Histeridae, and Staphylinidae families), and phytophagous (most abundant of which are Chrysomelidae, Curculionidae, and Scolytidae families). The mean numbers of the different trophic groups in each trap were determined and the results show that the highest values are the same depending on the type of trapping in both sites studied. Phytophagous recorded higher size $(p<0.05)$ in the yellow trap height, the screen trap, and the yellow trap on the ground with general average of $32.08 \pm 3.69$ in Bongo and $32 \pm 2.69$ in Toupah. But, from the ground yellow trap in Bongo and the screen trap in Toupah, the abundance of phytophagous insects does not show any obvious change compared to the other insects trophic groups (p $>0.05)$, as displayed in Tables 2 and 3. For the pitfall trap, predators displayed higher size $(\mathrm{p}<$ $0.001)$ in both Bongo and Toupah sites $(22.08 \pm 3.2$ and $13.41 \pm 1.38$, respectively) compared to the detritiphagous and phytophagous insects (Tables 3 and 4).

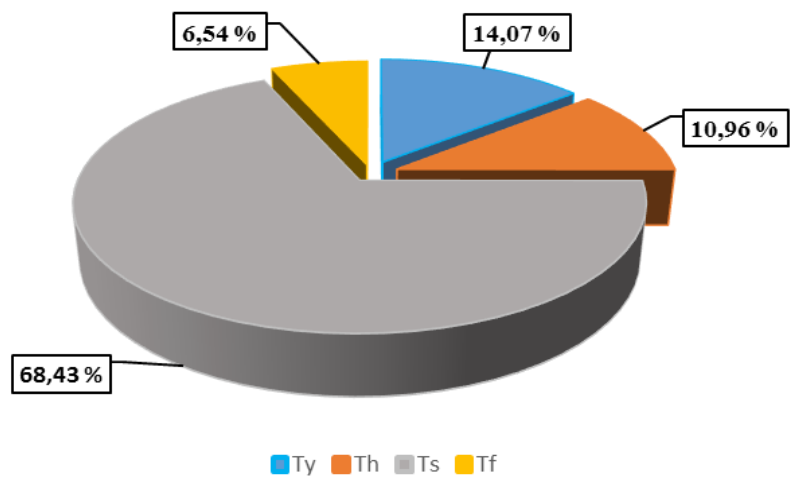

Figure 6: Rates of beetles in traps from Toupah (Ty: Yellow ground trap, Th: yellow height trap, Ts: Screen trap and Tf: Pitfall trap).

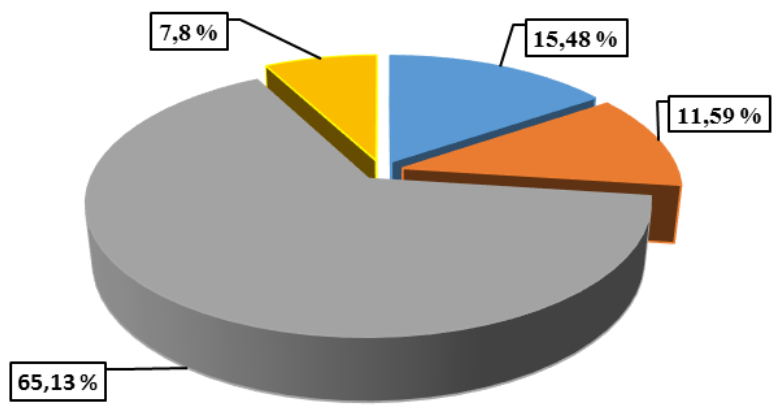

Ty Th DT

Figure 7: Rates of beetles in traps from Bongo (Ty: Yellow ground trap, Th : yellow height trap, Ts: Screen trap and Tf : Pitfall trap). 


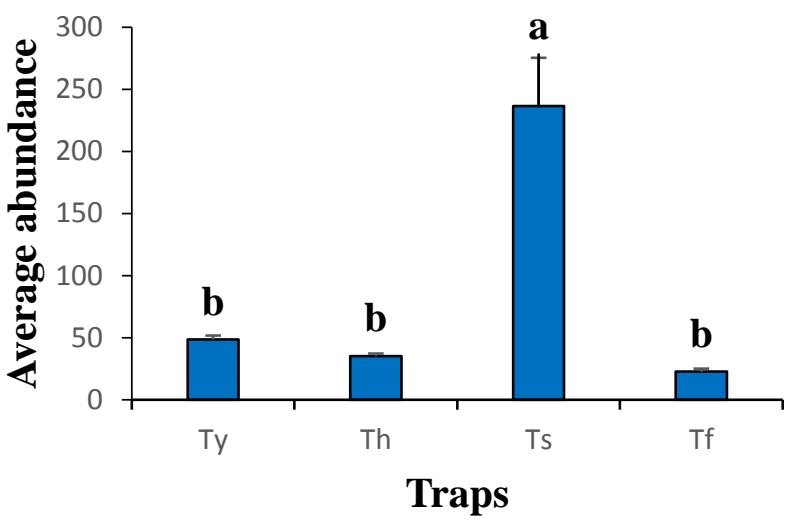

Figure 8: Effectiveness of beetles' trapping techniques in Toupah (Ty: Yellow ground trap, Th: yellow height trap, Ts: Screen trap and Tf: Pitfall trap).

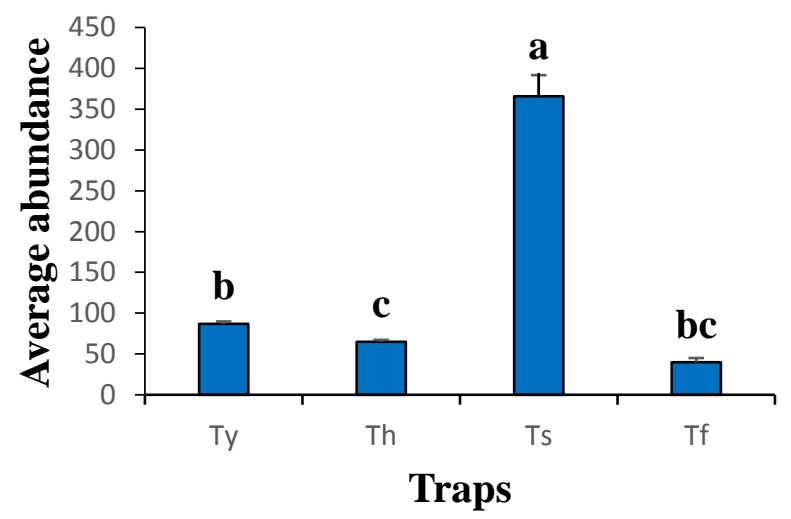

Figure 9: Effectiveness of beetles' trapping techniques in Bongo (Ty: Yellow ground trap, Th: yellow height trap, Ts: Screen trap and Tf: Pitfall trap).

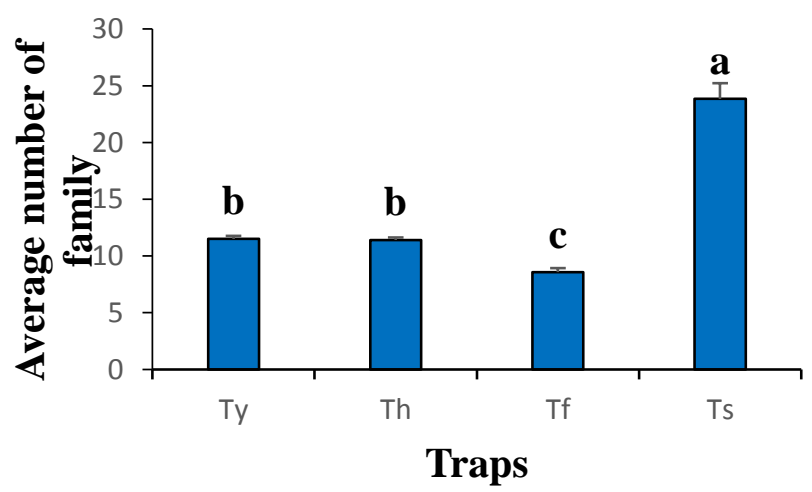

Fig 10: Comparison of average family richness in Bongo traps (Ty: Yellow ground trap, Th: yellow height trap, Ts: Screen trap and Tf: Pitfall trap). 


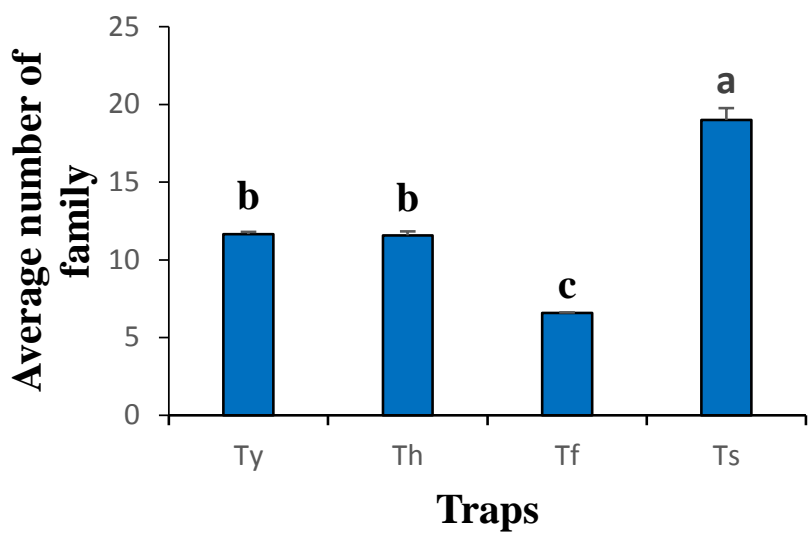

Fig 11: Comparison of average family richness in Toupah traps (Ty: Yellow ground trap, Th: yellow height trap, Ts: Screen trap and Tf: Pitfall trap).

Table 1: Capture of each trap in plantations at Bongo.

\begin{tabular}{|c|c|c|c|c|c|}
\hline \multirow{2}{*}{ Traps } & \multicolumn{4}{|c|}{ Insects habitats } & \multirow{2}{*}{$\mathbf{P}_{\text {-value }}$} \\
\hline & 1 to 5 years & 6 to 10 years & $>15$ years & Forest & \\
\hline Ty & $42.08 \pm 5.22^{\mathrm{Ab}}$ & $18.83 \pm 2.67^{\mathrm{Bb}}$ & $15.25 \pm 2.45^{\mathrm{Bb}}$ & $12 \pm 2.64^{\mathrm{Bb}}$ & $<0.001$ \\
\hline $\mathrm{Tf}$ & $12.75 \pm 1.98^{\mathrm{ABd}}$ & $16.91 \pm 2.68^{\mathrm{Ab}}$ & $4.91 \pm 1.2^{\mathrm{Bc}}$ & $9.16 \pm 1.56^{\mathrm{Bb}}$ & $<0.001$ \\
\hline Th & $28.25 \pm 7.87^{\mathrm{Ac}}$ & $10.08 \pm 2.96^{\mathrm{Bb}}$ & $18.16 \pm 4.54^{\mathrm{ABb}}$ & $8.5 \pm 1.04^{\mathrm{Bb}}$ & 0.022 \\
\hline Ts & $56.16 \pm 11.12^{\mathrm{Ba}}$ & $54 \pm 7.54^{\mathrm{Ba}}$ & $93.41 \pm 14.25^{\mathrm{Ba}}$ & $161.66 \pm 23.4^{\mathrm{Aa}}$ & $<0.001$ \\
\hline $\mathbf{P}_{\text {-value }}$ & 0.003 & $<0.001$ & $<0.001$ & $<0.001$ & \\
\hline \multicolumn{6}{|c|}{$\begin{array}{l}\text { Per row/column, the values followed by the same superscript/lowerscript do not differ at 5\% significance (ANOVA-one way } \\
\text { and Fisher LSD Test). Ty: Yellow ground trap, Th: yellow height trap, Ts: Screen trap and Tf: Pitfall trap }\end{array}$} \\
\hline \multirow{2}{*}{ Traps } & \multicolumn{4}{|c|}{ Insects habitats } & \multirow{2}{*}{$\mathbf{P}_{\text {-value }}$} \\
\hline & 1 to 5 years & 6 to 10 years & $>15$ years & Forest & \\
\hline Ty & $19.33 \pm 1.62^{\mathrm{Ab}}$ & $11.5 \pm 1.46^{\mathrm{Bb}}$ & $8 \pm 2.24^{\mathrm{Bb}}$ & $8.5 \pm 0.9^{\mathrm{Bb}}$ & $<0.001$ \\
\hline $\mathrm{Tf}$ & $7.16 \pm 1.6^{\mathrm{ABb}}$ & $9.08 \pm 1.78^{\mathrm{Ab}}$ & $4.41 \pm 0.49^{\mathrm{BCb}}$ & $2.41 \pm 0.76^{\mathrm{Cab}}$ & 0.004 \\
\hline $\mathrm{Th}$ & $13.5 \pm 1.85^{\mathrm{Ab}}$ & $12.08 \pm 1.73^{\mathrm{ABb}}$ & $8.91 \pm 1.46^{\mathrm{Bb}}$ & $2.58 \pm 0.77^{\mathrm{Cab}}$ & $<0.001$ \\
\hline Ts & $46.75 \pm 7.68^{\mathrm{Ba}}$ & $64.91 \pm 12.33^{\mathrm{ABa}}$ & $45.16 \pm 10.54^{\mathrm{Ba}}$ & $102.91 \pm 23.39^{\mathrm{Aa}}$ & 0.041 \\
\hline $\mathbf{P}_{\text {-value }}$ & $<0.001$ & $<0.001$ & $<0.001$ & $<0.001$ & \\
\hline
\end{tabular}

Per row/column, the values followed by the same superscript/lowerscript do not differ at $5 \%$ significance (ANOVA-one way and Fisher LSD Test). Ty: Yellow ground trap, Th: yellow height trap, Ts: Screen trap and Tf: Pitfall trap. 
Table 3: Sizes of trophic groups resulted from the insects captured in traps from Bongo.

\begin{tabular}{lllll}
\hline \multirow{2}{*}{ Traps } & \multicolumn{3}{c}{ Trophic Groups } & \multirow{2}{*}{ P-value $_{\text {-ven }}$} \\
\cline { 2 - 4 } & Predators & Detritiphagous & Phytophagous & \\
\hline Ty & $29.16 \pm 4.03^{\mathrm{Aa}}$ & $25.58 \pm 3.21^{\mathrm{Aa}}$ & $32.08 \pm 3.69^{\mathrm{Ab}}$ & 0.462 \\
Tf & $22.08 \pm 3.2^{\mathrm{Aa}}$ & $18.33 \pm 3.16^{\mathrm{Aa}}$ & $3.33 \pm 0.73^{\mathrm{Bc}}$ & $<0.001$ \\
Th & $21.08 \pm 3.21^{\mathrm{Aa}}$ & $19.66 \pm 2.69^{\mathrm{Aa}}$ & $24.25 \pm 9.52^{\mathrm{Ab}}$ & 0.859 \\
Ts & $92.58 \pm 10.77^{\mathrm{Bb}}$ & $102 \pm 12.85^{\mathrm{Bb}}$ & $170.90 \pm 19.39^{\mathrm{Aa}}$ & $<0.001$ \\
\hline P-value & $<0.001$ & $<0.001$ & $<0.001$ &
\end{tabular}

Per row/column, the values followed by the same superscript/lowerscript do not differ at 5\% significance (ANOVA-one way and Fisher LSD Test). Ty: Yellow ground trap, Th: yellow height trap, Ts: Screen trap and Tf: Pitfall trap.

Table 4: Sizes of trophic groups resulted from the insects captured in traps from Toupah.

\begin{tabular}{lllll}
\hline \multirow{2}{*}{ Traps } & \multicolumn{3}{c}{ Trophic Groups } & \multirow{2}{*}{ P-value } \\
\cline { 2 - 4 } & Predators & Detritiphagous & Phytophagous & \\
\hline Ty & $9.91 \pm 1.2^{\mathrm{Bb}}$ & $8.5 \pm 1.59^{\mathrm{Bb}}$ & $32 \pm 2.69^{\mathrm{Ab}}$ & $<0.001$ \\
Tf & $13.41 \pm 1.38^{\mathrm{Aa}}$ & $7.16 \pm 1.09^{\mathrm{Ab}}$ & $2.83 \pm 0.36^{\mathrm{Bc}}$ & $<0.001$ \\
Th & $6.75 \pm 0.82^{\mathrm{Bb}}$ & $7.66 \pm 1.19^{\mathrm{Bb}}$ & $23.41 \pm 2.31^{\mathrm{Ab}}$ & $<0.001$ \\
Ts & $58 \pm 6.74^{\mathrm{Ba}}$ & $75.5 \pm 14.25^{\mathrm{Ba}}$ & $100.33 \pm 36.31^{\mathrm{Aa}}$ & $<0.001$ \\
\hline P-value & $<0.001$ & $<0.001$ & $<0.001$ &
\end{tabular}

Per row/column, the values followed by the same superscript/lowerscript do not differ at 5\% significance (ANOVA-one way and Fisher LSD Test). Ty: Yellow ground trap, Th: yellow height trap, Ts: Screen trap and Tf: Pitfall trap.

\section{DISCUSSION}

The beetles' abundance varies according to the trapping techniques. For each trap type, there is a strong similarity between the proportions of individuals collected in both sites studied.

Generally, the screen traps captured more individuals, with a proportion of over $65 \%$ of insects individuals. Such a higher proportion of capture has been previously reported Lhoir et al. (2003) who collected respectively $77 \%$ and $48 \%$ total beetles individuals using the screen. The large intercepting surface of this trap could be advantageous for the capture of numerous insects. Chapelin and Mezeray (2013) have also highlighted the effectiveness of the screen trap on several taxa (Coleoptera, Heteroptera, Lepidoptera, Mecoptera, and Neuroptera). These authors mentioned the size of the interception surface and the exhibition location as significant parameters for efficiency in insects captures.

The screen traps could be effective for worse sailboats insects such as beetles, oppositely to the Malay trap which is reported to be effective for adults, mobile, and good sailing ship insects, and from several orders of insects (Diptera, Hymenoptera) in tropical environment (Lamarre et al., 2012). Indeed, beetles hitting the screen during the fly usually try to overcome this obstacle by descending below for getting around, and so they are unfortunately captured in the receptacle located under the screen. Oppositely, adults and good sailboats skip the obstacle from the top size. The abundance of capture using the screen trap increases with the amount of systematic insects' family, showing that this trap does not reveal specificity for any type of insects. Thus, 
every flying insect is likely to be captured by the screen trap, forecasting the abundance of overall trophic groups and especially adult beetles.

The yellow ground and height traps are more effective in younger rubber farms compared to the rainy forest. Young plantations are known to be open habitats in which insects can easily move and perceive the attractive yellow colour. Our results disagree with those of Kra (2008) who reported higher abundance of beetles from the height traps in the forest. The difference could be due to the complexity of the environment and to the location of the trap. In fact, the traps need to be visible by insects for becoming effective in their capture. So, from the young rubber farms, the clarity and the lower or inexistent canopy are advantageous for the strong ability of insects capture in the ground yellow trap. Besides, within the rainy forest where the canopy remains duly abundant, the visibility is really reduced and the yellow pots are not easily perceived by insects, so that they do not move toward the traps. Phytophagous beetles are the most abundant insects in the yellow traps compared to predators and detritiphagous. The yellow color is very attractive for flowering insects and foragers as mentioned by Yattara et al. (2013) and Lhoir et al. (2003). The perception of the yellow color and the shape of the plant could divert the insects towards these traps. Pitfall traps have a low proportion of collected individuals and make them the least effective compared to yellow and yellow screen traps and traps. Concerning these traps, their small proportions in number of individuals collected would be due to the specificity of this trap to capture the soil insects dominated largely by the Hymenoptera and Orthoptera and very little by the Coleoptera. Pitfall traps are most effective in the 6- to 10-year-old plantation and are less so in plantations older than 15 years and the forest. Work et al. (2002), Koivula et al. (2003) and Lange et al. (2011) mention that the effectiveness of this trap is also due to the diameter of the pot. These authors state that the abundance of insects increases with the diameter of the pot. The diameter used in our study is $10 \mathrm{~cm}$, which could have induced a low abundance of beetle within this trap. Also, the structure of the soil surface would be an obstacle to a good catch as Koivula et al. (2003). In fact, plantations 6 to 10 years old are less closed, with a less dense canopy compared to old plantations and forest and a less dense surface of the soil compared to plantations aged 1 to 5 years in which plants blankets make it difficult to set traps and therefore catch insects. Thus, plantations aged 6 to 10 years would be best suited for the capture of terricolous beetles. Family wealth in this trap would consist of few families as stipulated by Lang et al. (2011) who in this work showed that diversity does not increase with the diameter of the pot unlike abundance. Predators such as Carabidae and Staphylinidae and detritiphagous such as Scarabaeidae and Scydmaenidae were the most abundant in these traps. Several authors (Work et al., 2002, Lang et al., 2011 and Skvaria et al., 2017) have emphasized the abundance of Carabidae in pit traps. These insects for the most part live in burrows, under rocks and twigs and would be better adapted to running on the ground hence their abundance in this type of trapping.

\section{Conclusion}

The study shows the efficiency of the screen trap in terms of both abundance of insects individuals catches and abundance of insects families. This trap is the most suitable one for studying the diversity and abundance of beetles in rubber plantations. Nevertheless, pitfall traps are more effective in capturing the soil-inhabiting beetles dominated by the predators group. The yellow ground and height traps were more effective for the phytophagous group. Apart from the effectiveness of the traps, a combination of several trapping techniques could be adapted to diverse habitats, from the most opened to the densest, and it could thus be possible to compare the samples collected from various sites or dates.

\section{COMPETING INTERESTS}

The authors declare that they have no competing interest regarding this article. 


\section{AUTHORS CONTRIBUTIONS}

ASDD and BGD, the initiator of the article, entered the data from the inventory, analyzed the data, interpreted it and drafted the document. FD, NIB, DST and NBG contributed to the review of the data entered and analyzed, and to the critical review of the content of the article. FD helped interpret the data and critically review the content of the article. MD contributed to the analysis of the data and its interpretation, directed, read and corrected the document.

\section{ACKNOWLEDGMENTS}

We thank the African Rubber Plantation Society (Toupah and Bongo Integrated Agricultural Units), which has made available to us various rubber plantations in which the studies were carried out.

\section{REFERENCES}

Abé J. 2005. Contribution à la connaissance de la morphologie et de la dynamique sédimentaire du littoral ivoirien (cas du littoral d'Abidjan) essais de modélisation en Vue d'une gestion rationnelle. Diplôme de doctorat d'Etat en sciences naturelles, Université de Cocody Abidjan (Côte d'Ivoire), $352 \mathrm{p}$.

Barbalat S. 1995. Efficacité comparée de quelques méthodes de piégeage sur certains Coléoptères et influence de l'anthophilie sur le résultat des captures. Bulletin de la Société Neuchaleloise des Sciences Naturelles, 118 : 39-52. DOI : http://doi.org/10.5169/seals-89426

Carpaneto GM, Mazziotta A, Piattella E. 2005. Changes in food resources and conservation of scarab beetles from sheep to dog dung in a green urban area of Rome (Coleoptera, Scarabaeoidea). Biological Conservation, 123: 547-556. DOI: https://doi.org/10.1016/j.biocon.2004.12. 007

Chapelin-viscadi J-D, Mezeray JM. 2013. L'entomologiste Picard. 23, 11 p.

Danon ASD, Kra KD, Kwadjo KE, Douan BG, Loukou KKS, Doumbia M. 2017. Abondance et distribution des Coléoptères coprophages selon l'âge des plantations d'hévéa dans la localité de Toupah, au sud de la Côte d'Ivoire. Afrique Science, 13(1) : 421-434.

Delvare G, Aberlenc HP. 1989. Les Insectes d'Afrique et d'Amérique Tropicale; Clés pour la Reconnaissance des Familles. Prifas-Cirad: 34032 Montpellier Cedex 1, France

Hangay G, Zborowski P. 2010. Guide of beetles of Australia, $249 \mathrm{p}$.

Horgan FG. 2005. Effects of deforestation on diversity, biomass and function of dung beetles on the eastern slope of the Peruvian andes. Forest Ecology and Management, 216: 117-133. DOI : https://doi.org/10.1016/j.foreco.2005.05. 049

Kangha A, Konan E, Alla AD, Ouattara MA. 2016. Cartographie par télédétection et analyse de l'influence des activités agricoles dans le terroir villageois odjoukrou (à l'ouest d'Abidjan, Côte d'Ivoire). Institut de Géographie Tropicale (IGT), Université Félix Houphouët Boigny, Abidjan, Côte d'Ivoire, $15 \mathrm{p}$.

Keli ZJ, Omont H, Assiri AA, Boko CMAK, Obouayeba S, Dea BG, Doumbia A. 2005. Associations culturales à base d'hévéa : bilan de 20 années d'expérimentations en Côte d'Ivoire. Agronomie Africaine, 17 (1): 37-52. DOI: 10.4314/aga.v17i1.1656

Koivula MK, Hiisivuori DJ, Rita H. 2003. Pitfall trap efficiency: Do trap size, collecting fluid and vegetation structure matter? Entomologica Fennica, 14: 1-14. DOI: https://doi.org/10.33338/ef.84167

Kra KD, Klimaszewski J, Doumbia M, Aidara D, Dagnogo M. 2008. Comparing beetle abundance and diversity values along a land use gradient in tropical Africa (Oumé, Ivory Coast). Zoological Studies, 47(4): $\quad 429-437 . \quad$ DOI: http://zoolstud.sinica.edu.tw/Journals/47. $4 / 429$

Kra DK, Doumbia M, Klimaszewski J. 2010. Assessment of beetle abundance and diversity by four methods of capture in the west-central part of Oumé, Ivory 
Coast. Journal of Animal and Plant Sciences, 6 (1): 579- 588.

Lamarre GPA, Malto Q, Fine PVA, Baraloto C. 2012. A comparaison of two common flight interception traps to survey tropical arthropods. Zookeys, 216: 43-55. DOI: https://doi.org/10.3897/zookeys.216.333 2

Lang M, Gossner MM, Weisser WW. 2011. Effect of pitfall trap and diameter on vertebrate by-catches and ground beetle (Coleoptera: Carabidae) and spidae (Araneae) simpling. Methods in Ecology and Evolution, 2: 185-190. DOI: https://doi.org/10.1111/j.2041210X.2010.00062.x

Leraut P. 2003. Le Guide Entomologique. Delachaux et Niestlé : Paris ; 527p.

Lhoir J, Fagot J, Thieren Y, Gilson G. 2003. Efficacité du piégeage par les méthodes classiques des Coléoptères saproxyliques en Région Wallone (Belgique). Nautes Faunistiques de Gembloux, 50 : 49-61.

Moraes RM, Mendonga MD, Ott R. 2013. Carabid beetle assemblages in three environments in the Araucaecia humid forest of Southern Brazil. Revista Brasileira de Entomoloia, 57 (1): 67-74. DOI : http://dx.doi.org/10.1590/S008556262013000100011

Nicole MC. 2002. Les relations des insectes phytophages avec leur plantes hôtes. Antennae, 9 (1) : 5 -9.

Ruf F. 2008a. La fièvre caoutchouc. Jeune Afrique, (2457) : $56 \mathrm{p}$.

Ruf F. 2008b. Côte d'Ivoire : la terre de plus en plus chère. Grain de Sel, 43 : 5-6.
Skvaria MJ, Dowling APG. 2017. A comparaison of trapping technique (Coleoptera: Carabidae, Buprestidae, Cerambycidae and Curculionidae excluding Scolytidinae). Journal of Insect Science, 17(1): 1-28. $\quad$ DOI: 10.1093/jisesa/iew098

Tahiri A, Mangué JJ. 2007. Stratégies d'attaques de jeunes plants d'Hévéa par les termites et effet comparés de deux insecticides utilisés pour leur protection en basse Côte-d'Ivoire. Sciences et Nature, 4(1): 45-55. DOI: 10.4314/scinat.v4i1.42129

Tahiri AY. 2010. Termites ravageurs de l'hévéa Hevea brasilensis dans les départements de Daoukro et d'Agboville (Côte d'Ivoire). Lutte par utilisation des extraits de 6 plantes locales contre le termite champignonniste Macrotermes bellicosus, Thèse de Doctorat d'États essciences Naturelles, $223 \mathrm{p}$.

Work TT, Buddle CM, Korinus LM, Spence JR. 2002. Pitfall trap size and capture of three taxa of litter-dwelling Arthropods: Implication for biodiversity studies. Environmental Entomology, 31 (3): 438448. DOI: https://doi.org/10.1603/0046225X-31.3.438

Yattara AAA, Francis F. 2013. Impact des méthodes de piégeage sur l'efficacité de surveillance des pucerons: Illustration dans les champs de pomme de terre en Belgique. Entomologie Faunistique Faunistic Entomology, 66 : 89-95. 